\title{
Influence of LPS, TNF, TGF-B1 and IL-4 on the expression of MMPs, TIMPs and selected cytokines in rat synovial membranes incubated in vitro
}

\author{
ANNA HYC, ANNA OSIECKA-IWAN, JUSTYNA NIDERLA-BIELINSKA and STANISLAW MOSKALEWSKI
}

Department of Histology and Embryology, Medical University of Warsaw, Chalubinskiego 5 St., PL02-004 Warsaw, Poland

Received July 30, 2010; Accepted September 28, 2010

DOI: $10.3892 / \mathrm{ijmm} .2010 .550$

\begin{abstract}
Synovial membranes are formed by four main types of cells, i.e. fibroblasts, macrophages, epitheliocytes and adipocytes. To study the combined effect of various factors on these cell populations, synovial membranes dissected from rat knee joints were incubated in control medium or medium with lipopolysaccharide (LPS), TNF, TGF- 31 or IL-4 for $12 \mathrm{~h}$. LPS stimulated TNF secretion and both agents stimulated secretion of IL-6. TGF- 31 slightly increased IL-6 secretion. LPS increased the mRNA levels of IL-6, IL-1ß, TGF-ß1, MMP1a, MMP1b, MMP3, MMP9, MMP13, MMP14, TIMP1 and TIMP3 while the mRNA levels of MMP2, TIMP2 and TIMP4 were significantly decreased. Expression of IL-1ß, MMP1a, MMP1b, MMP3, MMP9, MMP13 and TIMP1 increased after TNF treatment, while mRNA levels of MMP2, MMP14, TIMP2, TIMP3 and TIMP4 were decreased. TGF- $\$ 1$ decreased the mRNA levels of IL-1ß, all MMPs, TIMP1, TIMP2, TIMP4 and increased mRNA levels of itself and TIMP3. IL-4 decreased mRNA levels of IL-1ß, TGF-ß1, MMP2, MMP9, MMP13 and all TIMPs. Only LPS decreased the amount and activity of MMP2. The effect of LPS and cytokines on most of the MMPs and TIMPs produced by whole synovial membrane was in good agreement with previous studies on their action on similar types of cells as those present in synovial membranes, but originating from other tissues. All tested agents decreased MMP2 mRNA expression levels and in the case of LPS also the protein level and its activity determined by zymography, contrary to previous observations on isolated cell populations. This indicates that the response of the organized tissue is an interplay of all components and cannot be deduced from the individual reactions.
\end{abstract}

Correspondence to: Dr Justyna Niderla-Bielinska, Department of Histology and Embryology, Medical University of Warsaw, Chalubinskiego 5 St., PL02-004 Warsaw, Poland

E-mail: justynan@ib.amwaw.edu.pl

Key words: synovial membrane, lipopolysaccharide, cytokines, metalloproteinases, tissue inhibitors of metalloproteinases, interleukin, transforming growth factor- $\beta$, tumor necrosis factor

\section{Introduction}

The synovial membrane defined in anatomy textbooks as the vascular connective tissue which produces the synovial fluid (1) is composed of the synovial lining and the subsynovium (2). The synovial lining, also called the synovial intima (3), consists of macrophage-like type A cells and fibroblast-like B cells (4-6). It is supported by the highly vascularized subsynovium, consisting of loose alveolar tissue, dense fibrous tissue and fat pad (2).

Most of the studies on the cells present in the synovial membrane deal with the cells forming the synovial lining which are traditionally called synoviocytes, although according to Wilkinson et al (3) the use of the term 'synoviocyte' should be restricted to the fibroblast-like cells since this is probably the only cell type chararacteristic of synovial tissue.

The population of mononuclear cells of hematopoietic origin isolated from synovium-rich rat tissues is dominated by two types of cells. The first type represents cells with the morphology and immunophenotype of macrophages that resemble type A synoviocytes. The second type belongs to indeterminate cells which under the influence of granulocyte macrophage colony-stimulating factor (GM-CSF) differentiate into mature dendritic cells $(7,8)$. Interestingly, in an EM study, Nozawa-Inoue et al (9) divided the macrophage-like A cells into two types i.e. electron-lucent with prominent vacuoles and lysosomes, and thus corresponding to the macrophage phenotype, and electron-dense cells, in which these organelles were less marked. The latter cells could correspond to the indeterminate cells described by Moghaddami et al $(7,8)$.

Synovial macrophages, similarly to macrophages from other tissues, originate from monocytes migrating from the bone marrow, express class II MHC molecules and are involved in antigen presentation $(7,9,10)$. Moreover, in the rat, they are positive for intracellular ED1 antigen present in cells of macrophage/monocyte lineage, and for ED2 antigen characteristic for tissue macrophages (11). Synovial type A cells remove particulate matter, antigens and other proteins from the synovial fluid by phagocytosis and endocytosis $(8,12-16)$. The proficiency for phagocytosis seems to be similar in peritoneal and synovial macrophages. However, some of the latter are considerably more endocytotic than peritoneal macrophages. This may be interpreted as an adaptation to the specific conditions in the joint, since 
efficient removal of debris and waste from the joint fluid is functionally important (8).

Synovial type B cells show high uridine diphosphoglucose dehydrogenase (UDPGD) activity (3), express hyaluronan synthases (HASs) $(17,18)$ and produce large amounts of hyaluronan (HA) which is deposited in the synovial lining (19) and is secreted continuously to maintain effective concentration within the joint (20). Moreover, synovial fibroblasts produce lubricin, a glycoprotein believed to be responsible for the low friction between the moving articular surfaces and which is not detected in other fibroblast-rich tissues (21). They also have a high content of prolyl hydroxylase essential for collagen synthesis $(3,22)$ and produce other elements of the extracellular matrix, such as fibronectin (23) and laminin. The latter concentrates at the basal aspects of the fibroblast-like synoviocytes and forms discontinuous, basement membrane-like structures (24). The $\mathrm{B}$ cells are also the main source of the synovial lining VCAM-1 and ICAM-1 $(22,25)$. Adhesion between type B cells is provided by cadherin-11 (26). Synovial type B cells also express heat shock protein Hsp25 which enables their immunocytochemical detection and together with scanning electron microscopy demonstration of their unique surface topography with intertwined slender processes covering the surface of synovial lining, thick and long processes extending into the joint cavity and with type A cells residing in the slits of this meshwork (27-29, cf. 30).

The functional characteristics of synoviocytes has usually been studied in cultures of fibroblasts and macrophages obtained from normal or pathological synovial membrane. Interaction of activated macrophages and fibroblasts is critical for the resulting inflammation and tissue damage in RA (cf. 31,32) and OA (33).

The responses of macrophages and fibroblasts from healthy tissues to cytokines and other factors has been extensively studied $(34,35)$. Since both types of synoviocytes produce cytokines, matrix metalloproteinases (MMPs) and other factors, they may influence each other, and thus their combined response in normal synovium may differ from that of the single cell type. Furthermore, cytokines produced by endothelial cells (36) or cytokines and hormones produced by adipocytes present in the subsynovium may also modify the synoviocyte response (37-40). Thus, studies concerning chosen populations of cells forming the synovial membrane may not be representative of the whole organ.

We have recently demonstrated that synovial membrane dissected from rat knee joints responded to stimulation by pro- and anti-inflammatory cytokines by increasing production of HA (41). In this work we have studied the influence of LPS and of several cytokines on the expression of cytokines, MMPs, and tissue inhibitors of metalloproteinases (TIMPs) at the mRNA and protein level, in order to obtain information on the reaction of the whole synovial membrane to various stimuli.

\section{Materials and methods}

Animals. Synovial membranes were obtained from inbred, 3 month-old Lewis male rats. Animals, kept in pathogen-free conditions, were obtained from the Animal Unit of the
Mossakowski Medical Research Centre, Polish Academy of Sciences, Warsaw. The study and the methods were approved by the Animal Ethics Committee of the Medical University of Warsaw.

Preparation of rat synovial membranes. After opening of the knee joint cavity, the synovial membrane was excised together with the patella, the patellar ligament and the joint capsule. Next, the synovial membrane with the infrapatellar fat pad was separated from the other tissues according to the method previously described (42).

Incubation of synovial membranes. Synovial membranes were put into flat-bottomed 24-well plates (Corning, NY, USA) in $1 \mathrm{ml}$ of RPMI medium with $1 \%$ antibiotic and antimycotic solution (Sigma-Aldrich Chemie, Diesenhofen, Germany) for $12 \mathrm{~h}$ of incubation at $37^{\circ} \mathrm{C}$ in $5 \% \mathrm{CO}_{2}$ in air on a slow-motion shaker. The synovial membrane from one knee joint served as the control to the synovial membrane from the opposite knee. Experimental synovial membranes were exposed to $10 \mu \mathrm{g} / \mathrm{ml}$ of LPS, $10 \mathrm{ng} / \mathrm{ml} \mathrm{TGF-} \beta 1,20 \mathrm{ng} / \mathrm{ml}$ TNF (Sigma) or $10 \mathrm{ng} / \mathrm{ml} \mathrm{IL-4} \mathrm{(PromoKine,} \mathrm{PromoCell}$ $\mathrm{GmbH}$, Heidelberg, Germany). After incubation, the media were collected and stored at $-20^{\circ} \mathrm{C}$. Synovial membranes were used as a source of RNA. In a few additional experiments performed for evaluation of the mRNA expression under exposure to LPS and TNF the time of incubation was shortened to 1,2 or $3 \mathrm{~h}$.

ELISA assays for IL-6 and TNF determination. Cytokine level in supernatants was evaluated with rat immunoassay kits (Invitrogen Corporation, Camarillo, CA, USA), according to the manufacturer's protocols.

Total RNA isolation. Two synovial membranes (from two rats) were pooled. RNA was isolated with NucleoSpin ${ }^{\circledR}$ RNA II kit (Macherey-Nagel, Duren, Germany), according to manufacturer's protocol. The quantity of the isolated total RNA was measured with Picodrop (Picodrop Limited, Saffron Walden, UK). The quality of the isolated RNA was checked by electrophoresis in $1 \%$ agarose denaturing gel containing $6 \%$ formaldehyde and buffered with MOPS (Sigma). After electrophoresis, the gel was scanned with digital imaging system GDS 9000 using the Grab-It 2.0 software (UVP, Cambridge, UK).

Reverse transcription. Reverse transcription was performed using the High Capacity cDNA Reverse Transcription kit (Applied Biosystems, Cheshire, UK), according to the manufacturer's protocol in Eppendorf Mastercycler gradient. cDNA samples were stored at $-20^{\circ} \mathrm{C}$.

Real-time PCR. Real-time PCR was performed in the ABI PRISM 7500 (Applied Biosystems) using 96-well optical plates. Each sample was run in triplicate and was supplied with an endogenous control (Rat GAPDH endogenous control VIC ${ }^{\circledR} / \mathrm{MGB}$ Probe). For gene expression analysis, the following TaqMan expression assays were used: TIMP1Rn00587558_m1, TIMP2-Rn00573232_m1, TIMP3Rn00441826_m1, TIMP4-Rn01459159_m1, MMP1A- 
Rn01486507_m1, MMP1B-Rn01772485_g1, MMP2Rn01538167_m1, MMP3-Rn00591740_m1, MMP9Rn00579162_m1, MMP13-Rn01448195_m1, MMP14Rn00579172_m1, IL-1ß-Rn00580432_m1, IL-6-Rn01410330 _m1, TGF-ß1-Rn00572010_m1 and TNF-Rn99999017_m1. All probes were stained with FAM (Applied Biosystems). Reactions were run in $25 \mu 1$ of volume with TaqMan Universal Master Mix, appropriate primer set, MGB probe and $50 \mathrm{ng}$ of cDNA template. Universal thermal conditions, $10 \mathrm{~min}$ at $95^{\circ} \mathrm{C}, 40$ cycles of $15 \mathrm{sec}$ at $95^{\circ} \mathrm{C}$ and $1 \mathrm{~min}$ at $60^{\circ} \mathrm{C}$, were used. Data analysis was done with sequence detection software ver. 1.2 (Applied Biosystems).

Western blot analysis. Culture supernatants $(150 \mu 1)$ were lyophilised, resuspended in $30 \mu 1$ sample buffer with 2mercaptoethanol and separated by SDS-polyacrylamide gel electrophoresis (SDS-PAGE; 10\% acrylamide). Separated proteins were transferred onto PVDF membranes by semidry blotting at $25 \mathrm{~V}$ for 30 min using the Trans-Blot SD apparatus (Bio-Rad Laboratories, Hercules, CA, USA). Rabbit anti-TIMP1, TIMP2, TIMP4, MMP2 (Abcam, Cambridge, UK) and TIMP3 (Abbiotec, San Diego, CA) primary antibodies were used. The incubation lasted $1 \mathrm{~h}$. Biotinylated $\mathrm{F}(\mathrm{ab}) 2$ fragments of swine anti-rabbit immunoglobulins (Dako A/S, Glostrup, Denmark) served as the secondary antibody. Antibody binding was demonstrated by an amplified alkaline phosphatase detection system (Bio-Rad). To identify particular TIMPs, recombinant rat TIMP1 (R\&D Systems, Inc., Minneapolis, MN, USA), rat TIMP2 and human TIMP4 (Abcam) were used. The relative molecular weight of the proteins were calculated in relation to the prestained SDS-PAGE (low-range) standard (Bio-Rad). Intensity of the bands was measured by semi-quantitative densitometric analysis using GelWorks 2D-Intermediate software (UVP, Cambridge, UK).

Gelatin and casein substrate zymography. The MMP2, MMP9, MMP1 and MMP3 activity was detected by gelatin and casein zymography. Briefly, $10 \mu 1$ of culture medium in $10 \mu 1$ sample buffer (non-reducing conditions) was loaded onto gelatin or casein (both from Sigma) containing gels for SDS-PAGE (10\% polyacrylamide with $1 \mathrm{mg} / \mathrm{ml}$ gelatin or $0.08 \mathrm{mg} / \mathrm{ml}$ casein). After electrophoretic separation, the gels were washed twice for $30 \mathrm{~min}$ at room temperature in $2.5 \%$ Triton X-100 to remove SDS. For gelatin zymography the gels were washed subsequently in buffer containing $50 \mathrm{mM}$ Tris- $\mathrm{HCl}$ and $2.5 \%$ Triton $\mathrm{X}-100$ (pH 7.5) for 30 min, kept in $50 \mathrm{mM}$ Tris- $\mathrm{HCl}$ buffer (pH 7.5) with $5 \mathrm{mM} \mathrm{CaCl}_{2}, 1 \mu \mathrm{M}$ $\mathrm{ZnCl}_{2}$ and $2.5 \%$ Triton $\mathrm{X}-100$ for $30 \mathrm{~min}$ and incubated overnight in $50 \mathrm{mM}$ Tris- $\mathrm{HCl}$ with $5 \mathrm{mM} \mathrm{CaCl}, 1 \mu \mathrm{M} \mathrm{ZnCl}_{2}$ at $37^{\circ} \mathrm{C}$. For casein zymography the gels were incubated overnight at $37^{\circ} \mathrm{C}$ in reaction buffer containing $50 \mathrm{mM}$ Tris$\mathrm{HCl}$ buffer (pH 7.5) with $200 \mathrm{mM} \mathrm{NaCl}$ and $0.02 \% 23$ lauryl ether [Brij-35]. The gels were stained with $0.5 \%$ Coomassie Blue R-250 dissolved in $30 \%(\mathrm{v} / \mathrm{v})$ methanol and $10 \%(\mathrm{v} / \mathrm{v})$ acetic acid in $\mathrm{H}_{2} \mathrm{O}$ for $30 \mathrm{~min}$. The excess dye was washed away with the same solvent. Proteolytic activities appeared as clear bands of lysis against a dark background of stained gelatin or casein. Gelatinase bands were identified according to their molecular weight with purified recombinant MMP2

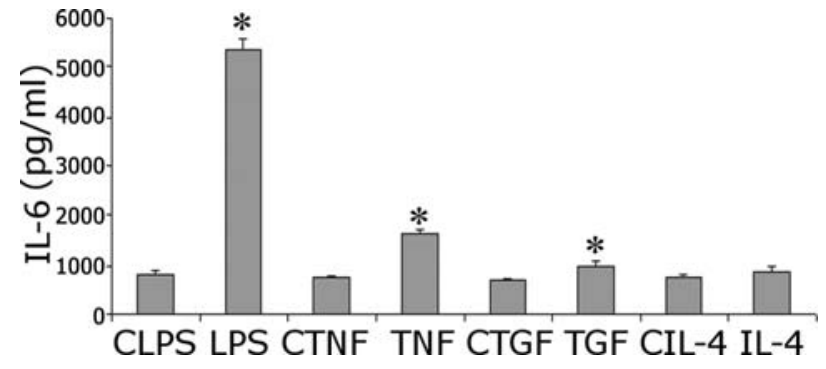

Figure 1. IL-6 concentration (mean $\pm \mathrm{SE}$ ) in control medium (C) and in medium containing LPS, TNF, TGF- 31 or IL-4 after $12 \mathrm{~h}$ incubation of the synovial membranes. In each group $n=6$. Differences between groups were significant, according to the Wilcoxon matched-pairs test at ${ }^{*} \mathrm{p}<0.05$.

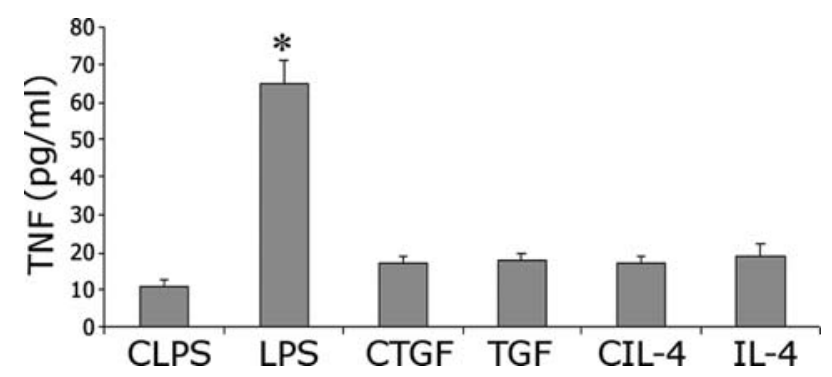

Figure 2. TNF concentration (mean $\pm \mathrm{SE}$ ) in control medium (C) and in medium containing LPS, TGF- 31 or IL-4 after $12 \mathrm{~h}$ incubation of the synovial membranes. In each group $n=6$. Differences between groups were significant, according to the Wilcoxon matched-pairs test at ${ }^{*} \mathrm{p}<0.05$.

and MMP9 (R\&D System) as standards. The gels were scanned with the digital imaging system GDS 90000 using Grab-It 2.0 software. The images were subjected to semiquantitative densitometric analysis using GelWorks 2DIntermediate software (UVP), in which the intensity of specific bands was measured.

Activity of TIMPs was determined by reversed zymography, using $25 \mu \mathrm{l}$ culture medium per lane. SDS-PAGE electrophoresis was done in $10 \%$ polyacrylamide gels with $1 \mathrm{mg} / \mathrm{ml}$ gelatin and $0.1 \mu \mathrm{g} / \mathrm{ml} \mathrm{MMP} 2$, using the procedure described above.

\section{Results}

To assess the quality of the dissection and the preparation of the synovial membranes, differences in cytokine levels in the culture medium of the synovium from the left and the right knee joint of the same rat were evaluated. There were no significant differences in cytokine levels (data not shown).

ELISA assays. Synovial membranes were stimulated with LPS, TNF or the anti-inflammatory cytokines, IL-4 and TGF- $\beta 1$, and the concentration of IL- 6 and TNF in the culture medium was evaluated. LPS strongly stimulated production of both tested cytokines. TNF caused a considerably lower increase of IL-6 production than LPS (influence of TNF on TNF production was not studied). TGF- $\$ 1$ caused a low but statistically significant increase of IL-6 production. IL-4 did not exert any influence on the levels of the tested cytokines (Figs. 1 and 2). 


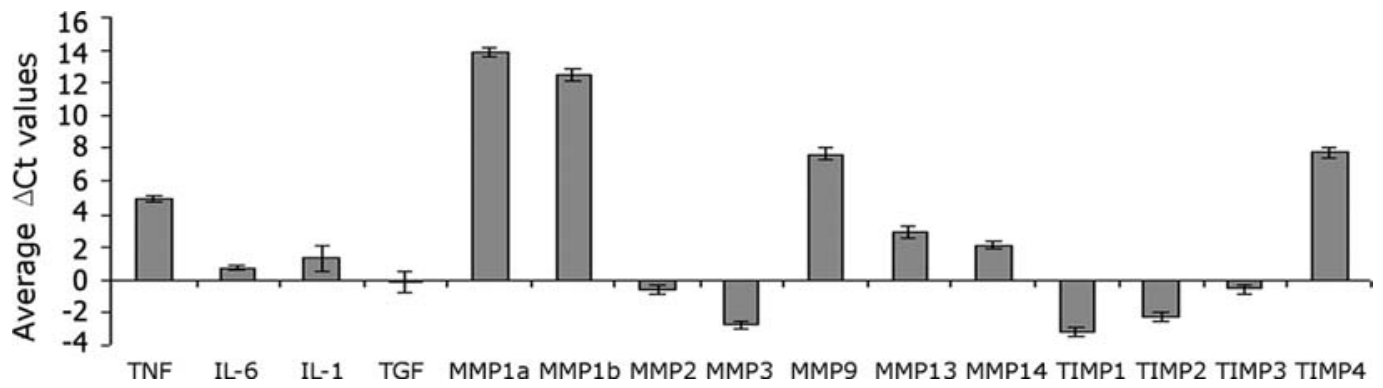

Figure 3. Average $\triangle \mathrm{CT}$ values $( \pm \mathrm{SD})$ as determined by real-time PCR by subtracting the average GAPDH CT value from the average cytokine, MMP or TIMP CT values in the control experiment ( $\mathrm{n}=30)$ calculated using sequence detection software ver. 1.2 (Applied Biosystems).
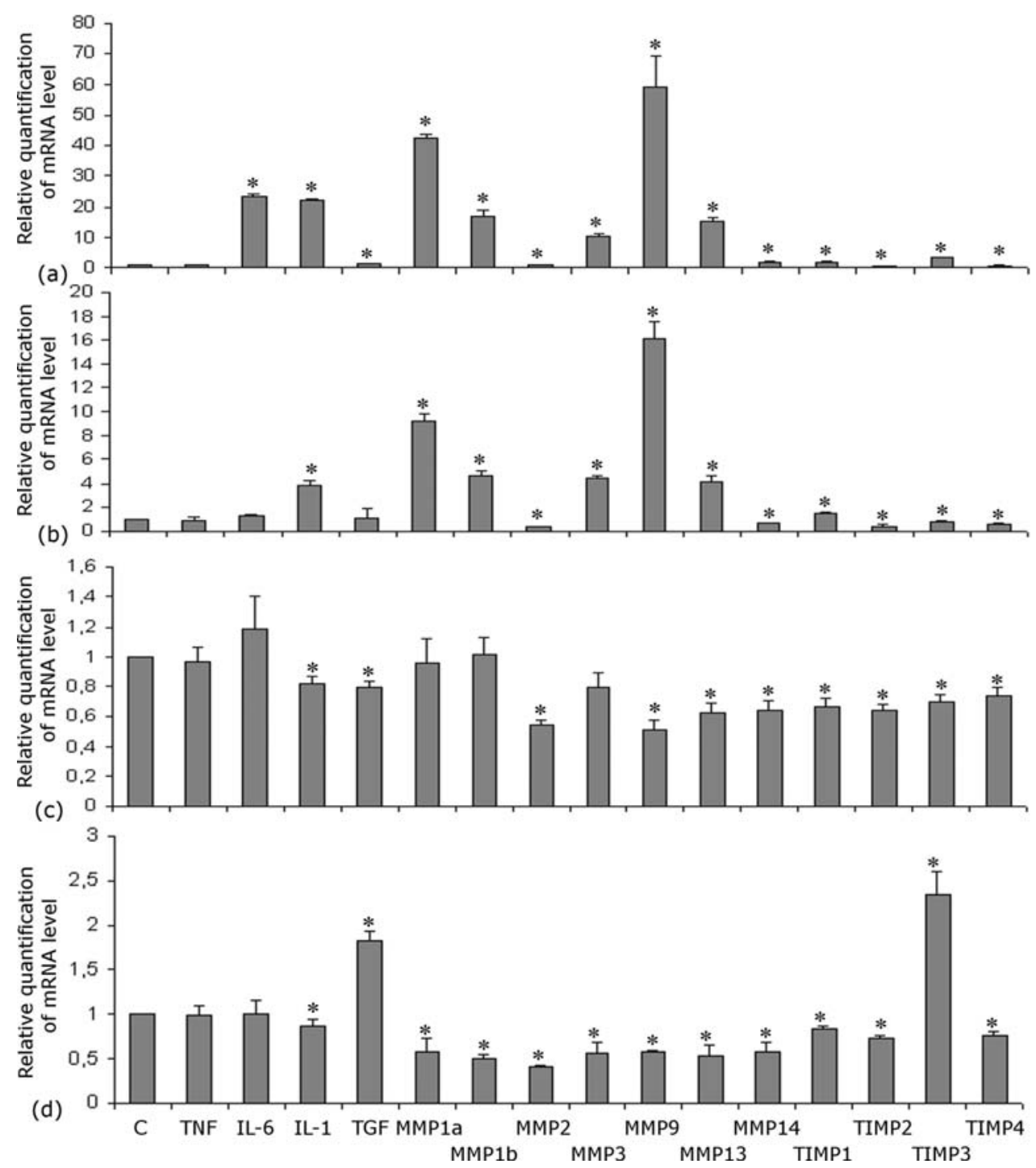

Figure 4. Mean values \pm SE of cytokine, MMP and TIMP mRNA levels in the synovial membrane after $12 \mathrm{~h}$ of incubation with (a) $10 \mu \mathrm{g} / \mathrm{ml} \mathrm{LPS}$, (b) $20 \mathrm{ng} / \mathrm{ml}$ TNF (c) $10 \mathrm{ng}$ IL-4 or (d) $10 \mathrm{ng} / \mathrm{ml}$ TGF- $\beta 1$ measured by real time PCR. In each group $\mathrm{n}=5$. Relative expression was calculated against the reference gene, GAPDH. Analysis was conducted as a relative quantification study, using control synovial membrane gene expression as a calibrator $($ value $=1)$. Differences between groups were significant, according to the Wilcoxon matched-pairs test at ${ }^{*} \mathrm{p}<0.05$.

Real-time PCR. The mRNA levels of all tested cytokines, MMPs, and TIMPs in the synovial membranes incubated in the control medium were compard to that of GAPDH mRNA $(\Delta \mathrm{Ct})$ which served as an endogenous control. The mRNA levels of MMP2, MMP3, TIMP1, TIMP2 and TIMP3 were higher while that of TGF- $\beta 1$ was approximately equal to the mRNA levels of GAPDH. Furthermore, the mRNA levels of IL-1ß, IL-6, MMP13 and MMP14 were slightly lower and those of TNF, MMP1a, MMP1b, MMP9 and TIMP4 were markedly lower than those of GAPDH (Fig. 3). 
(a)
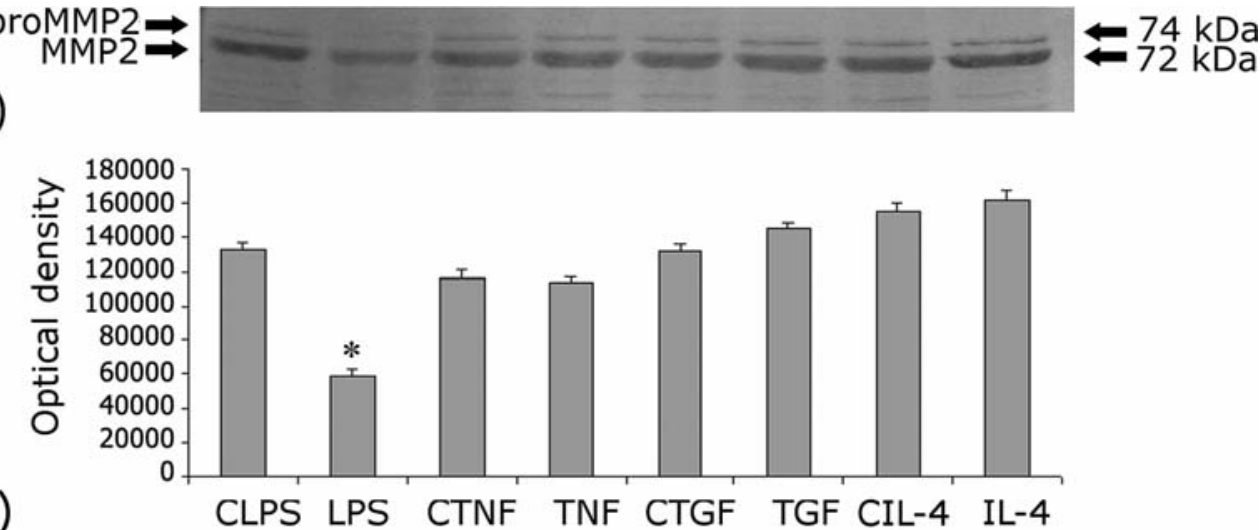

Figure 5. (a) SDS-PAGE and Western blot analysis of MMP2 in supernatants obtained after a $12 \mathrm{~h}$ incubation of synovial membranes in control media (C) and with LPS or cytokine stimulation. (b) Optical density of bands (mean \pm SE). In each group $n=5$. Differences between groups were significant, according to the Wilcoxon matched-pairs test at ${ }^{*} \mathrm{p}<0.05$.

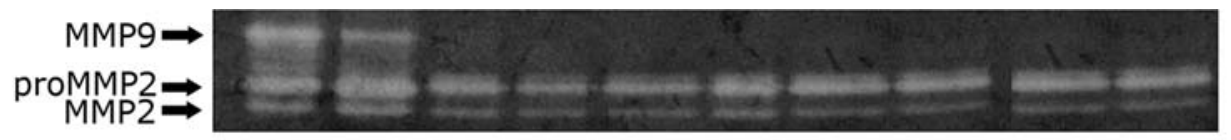

(a)

(b)

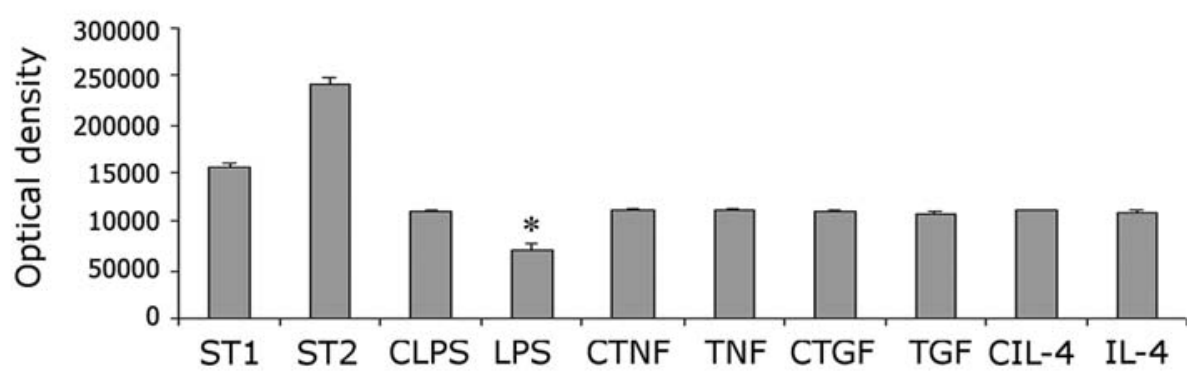

Figure 6. (a) Evaluation of gelatinase activity by gelatin zymography in supernatants obtained after $12 \mathrm{~h}$ incubation of synovial membranes in control media (C) or with LPS or cytokine stimulation. Lanes ST1 and ST2 (standard 1 and 2) contained recombinant human MMP2 and MMP9. ST1: 0.25 ng MMP2 and $0.5 \mathrm{ng}$ MMP9, ST2: $0.5 \mathrm{ng}$ MMP2 and $0.1 \mathrm{ng}$ MMP9. Activity of MMP9 was not detected. MMP2 was detected in all controls and samples in the pro-active and active forms. (b) Optical density of bands (mean $\pm \mathrm{SE}$ ). In each group $\mathrm{n}=5$. Differences between groups were significant, according to the Wilcoxon matched-pairs-test at ${ }^{*} \mathrm{p}<0.05$.

LPS caused a statistically significant increase in the mRNA levels of IL-6, IL-1ß, TGF-ß1, MMP1a, MMP1b, MMP3, MMP9, MMP13, MMP14, TIMP1 and TIMP3, and a significant decrease in the mRNA levels of MMP2, TIMP2 and TIMP4. LPS did not influence the expression of TNF mRNA after $12 \mathrm{~h}$ (Fig. 4a), but additional experiments demonstrated a 100-fold increase of the mRNA level at $1 \mathrm{~h}$, a 10 -fold after $2 \mathrm{~h}$ and a 3 -fold after $3 \mathrm{~h}$.

TNF decreased the mRNA levels of MMP2 and MMP14 and increased those of MMP1a, MMP1b, MMP3, MMP9 and MMP13. Expression of TIMP2, TIMP3 and TIMP4 decreased after TNF treatment while the mRNA levels of TIMP1 and of IL-1ß mRNA increased. The mRNA levels of TGF-ß1, IL-6 and TNF remained unchanged (Fig. 4b). In an additional experiment, IL- 6 mRNA expression was increased by 8 -fold after $3 \mathrm{~h}$ of incubation.

IL-4 stimulation decreased the mRNA levels of IL-1ß, TGF- 1 1, MMP2, MMP9, MMP13, MMP14 and of all TIMPs. The mRNA levels of IL-6, TNF, MMP1a, MMP1b and MMP3 were unchanged (Fig. 4c).
TGF- $\beta 1$ decreased the mRNA levels of IL-1ß, TIMP1, TIMP2, TIMP4 and of all MMPs, but increased the expression of TGF-B1 and TIMP3 mRNA. The mRNA levels of IL-6 and TNF remained unchanged (Fig. 4d).

Western blot analysis. MMP2 in its pro-active and active forms was identified in control and in all tested supernatants. LPS caused a decrease in the amount of this enzyme (Fig. 5). The amounts of TIMP1, TIMP2 and TIMP4 were similar in supernatants from LPS-, TNF-, TGF- 31 - and IL-4-stimulated membranes and did not differ from that in the controls (Fig. 7). TIMP3 was not detected in the control or the experimental groups.

Zymography. Gelatin zymography analysis was used to assess whether LPS, TNF, IL-4 and TGF- 31 influence the activity of MMP2 and MMP9 produced by synovial membranes. Gelatinolytic enzyme activity associated with proteins of molecular weights corresponding to $74 \mathrm{kDa}$ and $72 \mathrm{kDa}$ was detected indicating the presence of proMMP2, and the active 


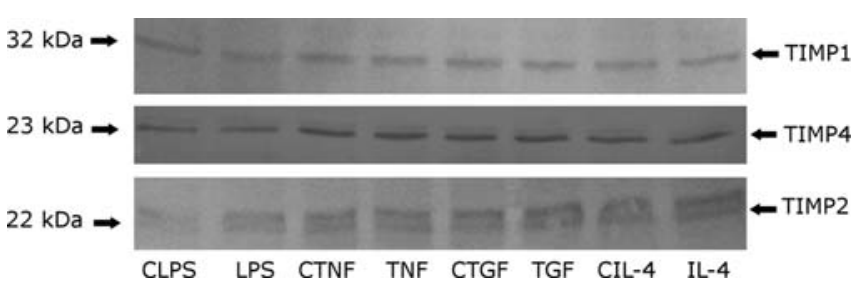

Figure 7. SDS-PAGE and Western blot analysis of TIMP1, TIMP2, TIMP4 in supernatants obtained after $12 \mathrm{~h}$ incubation of synovial membranes in control media (C) and with LPS or cytokine stimulation. In each group $n=5$. No differences were observed between controls and experimental groups.

form of MMP2, respectively. The activity of MMP9 was not detected. In media from LPS-stimulated membranes MMP2 activity was lowered, whereas TNF, IL-4 and TGF-B1 had no effect (Fig. 6). Caseinase activity was not detected.

Reversed zymography. The activity of TIMPs in media from control and synovial membranes stimulated with LPS, TNF, IL-4 and TGF- 31 was determined with reversed zymography. Only TIMP1 was detected and it was present in all the media. No difference was observed between control and stimulated membranes.

\section{Discussion}

Cytokine expression and secretion. The production of cytokines, proteolytic enzymes and their inhibitors by a complex tissue like the synovial membrane, presumably represents the net result of the activities of particular cell types and can be modified by factors released by these cells and reciprocally influencing their function. In our work stimulation of the synovial membrane by LPS increased secretion of TNF and IL-6 (Figs. 1 and 2). Previous studies have shown that macrophages express TNF mRNA (43) and that LPS augments their TNF expression at both the mRNA and protein levels $(44,45)$. Secretion of TNF by adipose tissue has also been described $(37,46,47)$, but it presumably had originated from macrophages residing within the tissue (48). Thus, most, if not all of the TNF released from the synovial membrane is likely produced by macrophages, since $\mathrm{T}$ cells in normal rat synovial membrane occur in insignificant number (49). The level of TNF mRNA measured after $12 \mathrm{~h}$ of LPS stimulation, which is our standard procedure, was similar to control. Since, however, in other studies the expression of TNF mRNA was raised much earlier and it returned to the control levels after several hours (50), we peformed an additional experiment with LPS stimulation lasting for 1-3 $\mathrm{h}$ and we observed a considerable increase in TNF mRNA expression.

Secretion of IL-6 after LPS stimulation was previously observed in synovial fibroblasts $(34,51,52)$, in endothelial cells $(34,51)$ and peritoneal macrophages $(43,44,53)$. Adipocytes were also shown to express and release IL-6 $(40,47,48)$. Thus, all four main cell types could contribute to the markedly increased expression of IL-6 at the mRNA and protein levels after LPS stimulation (Figs. 1 and 4a).

IL-1B transcript was present in the non-stimulated synovial membrane. Its level was considerably increased after
LPS stimulation (Fig. 4a). We have previously observed that LPS stimulation increased the content of IL- $1 \alpha$ in the synovial membrane lysates (42). Unstimulated rat monocytes or peritoneal macrophages do not express mRNA IL-1ß (43), but IL- $1 \alpha$ and IL-1ß were shown to be produced after LPS stimulation $(43,54,55)$. Moreover, LPS has been reported to stimulate IL-1 production by vascular cells (56), fibroblasts (34) and adipocytes (57). Thus, the IL-1ß transcript could originate from all the main cell types present in the synovial membrane. LPS also increased the mRNA level of TGF- 31 (Fig. 4a). LPS has been shown to stimulate the release of TGF-ß1 in endothelial cells (58) and the TGF- 31 expression in PMA-stimulated macrophages (59).

TNF also increased IL-6 secretion but with much less potency than LPS (Fig. 2). According to previous reports, TNF has no effect on IL-6 synthesis in monocytes and macrophages (60), but exerts a moderate stimulatory effect on the secretion of IL-6 by fibroblasts (61) and endothelial cells (51). Therefore, the increased production of IL-6 by the synovial membrane after TNF stimulation can be ascribed to the fibroblast-like synoviocytes and the endothelial cells. In spite of this increased secretory activity, the level of IL-6 mRNA was similar to the controls, but a rise was observed if stimulation was shortened to $3 \mathrm{~h}$. The mRNA levels of IL-1ß were moderately increased after TNF stimulation (Fig. 4b). Thus, our results are in accord with previous observations that after TNF stimulation, IL- $1 \alpha$ and IL-1ß are produced by monocytes, macrophages and vascular cells $(43,54-56)$.

TGF- $\$ 1$ exerted a weak stimulatory effect on IL-6 secretion by the synovial membrane, which, however, was unnoticeable at the mRNA level (Figs. 1 and 4d). TGF- 31 mRNA was previously found to be expressed by the fibroblast-like synoviocytes and the endothelial cells (34). TGF- 31 was shown to induce IL- 6 mRNA and protein expression in human fibroblasts $(62,63)$. There are, however, inconsistencies between reports on the influence of TGF- $\beta 1$ on monocytes. In one study TGF- $\beta 1$ was found to induce (64) and in another (65) to inhibit IL- 6 production. Thus, the main effect of the stimulatory action of TGF- 31 on IL-6 secretion was probably due to its action on the fibroblast-like synoviocytes, while contribution of the synovial macrophages remains uncertain. TGF- $\beta 1$ had no effect on TNF mRNA level (Fig. 4d). TGF-ß1 was previously found to suppress TNF production by peritoneal macrophages (66), presumably inhibiting translation of TNF mRNA $(67,68)$. Furthermore, TGF- $\beta 1$ decreased the expression of IL-1ß mRNA (Fig. 4d) in agreement with a previous report (69). In human PBMCs, TGF- 31 was shown to cause an increase in the mRNA levels of IL- $1 \alpha$ and IL-1ß (70). In our study, TGF- $\beta 1$ markedly stimulated the expression of TGF- $\beta 1$ mRNA (Fig. 4d) which is in good agreement with previous observations, that TGF- $\beta 1$ can induce its own gene expression in fibroblasts (71), and other cell types $(72,73)$.

IL-4 had no effect on TNF and IL-6 secretion or mRNA levels in the synovial membrane (Figs. 1, 2 and 4c). In previous studies IL-4 did not influence IL- 6 production in rheumatoid synovial fibroblasts or various fibroblast cell lines (74). However, IL-4 stimulated the production of TNF by mononuclear phagocytes $(75)$. Human umbilical vein endothelial cells stimulated by IL-4, in one study, produced 
only low amounts of IL-6 and expressed low levels of the IL-6 transcript (76), while in another it increased IL-6 production (77). Thus, the lack of IL-4 stimulatory action on TNF and IL-6 production observed by us is in accord with studies on fibroblasts, but differs from that on mononuclear phagocytes (75). The influence of IL-4 on the secretion of TGF-ß1 was not studied, but a small, although significant decrease of TGF-B1 mRNA levels was noted (Fig. 4c). In our work IL-4 slightly suppressed the mRNA levels of IL-1ß (Fig. 4c) which is in agreement with Te Velde et al (78) who described a decreased secretion of IL-1ß in human monocytes after IL-4 treatment, but in opposition to Lacraz et al (75) who observed increased production of IL-1 by mononuclear phagocytes.

MMPs. MMP2 (72 kDa gelatinase; gelatinase A, type IV-A collagenase), digests gelatin, fibronectin, laminin, collagen type $\mathrm{V}$ and to a lesser extent collagen type IV, cartilage proteoglycans and elastin (79). MMP2 is secreted as progelatinase and is activated by MMP14 (80). MMP2 is produced by synovial fibroblasts $(79,81,82)$, by macrophages, particularly after stimulation with LPS (83), and by endothelial cells $(84,85)$, particularly after stimulation with TGF-ß1 (86) or LPS (87). MMP2 is also produced by adipocytes (88). In our experiment, all agents tested, that is LPS, TNF, IL-4 and TGF- 31 , decreased the expression of MMP2 mRNA (Fig. 4a-d). Moreover, after LPS treatment the medium used for the synovial membrane contained less MMP2 protein as detected by Western blot analysis and less MMP2 activity as demonstrated in the zymography assay (Figs. 5 and 6).

MMP9 (92 kDa gelatinase; gelatinase B; type IV-B collagenase) digests gelatin, collagen types IV, V, XI, XVII, elastin, fibronectin, link proteins, aggrecan and several cytokines (cf. 89). Typically, MMP9 is secreted by cells as a proenzyme in a noncovalent complex with TIMP1. Interaction of MMP9 with TIMP1 prevents its dimerization, formation of the complex with MMP1 and activation by MMP3 $(89,90)$.

Secretion of MMP9, the most abundant gelatinase in macrophages, has been reported to be stimulated 3- to 4-fold after exposure of human alveolar macrophages to LPS (83). In monocytes and in monocyte-derived macrophages TNF also increased the production of MMP9 $(92,93)$. It is also noteworthy, that macrophages cultured on polymerized collagen, conditions which are roughly similar to those used for culturing synovial membrane, produced less MMP9 than when the cells were cultured on plastic, but strongly responded to TNF stimulation by increasing MMP9 expression (94). TNF has also been shown to stimulate the expression of MMP9 in endothelial cells (95).

Furthermore, MMP9 is expressed by adipocytes and is has been shown to be up-regulated in a macrophageconditioned medium, presumably due to its TNF content (96). Production of the $92 \mathrm{kDa}$ gelatinase has not been observed in synovial fibroblasts (82). In our work MMP9 expression was increased about 60 -fold after LPS stimulation. TNF also strongly stimulated MMP9 expression but less potently than LPS. Its expression was decreased by TGF- $\beta 1$ and IL-4, similarly to another study on mononuclear phagocytes (75) (Fig. 4a-d). Media from experimental and control cultures of synovial membranes, however, did not contain MMP9 gelatinolytic activity in the zymography assay.
This lack of demonstrable activity could be due to the low MMP9 concentration in the medium. In our work, expression of MMP9 mRNA in the control synovial membrane was distinctly lower than that of GAPDH used as a reference (Fig. 3) and even after LPS stimulation it did not reach its level. Another reason for the lack of MMP9 gelatinase activity could be the formation of an inactive enzymeinhibitor complex of MMP9 and the TIMPs $(89,97,98)$ present in the medium particularly considering the fact, that LPS stimulated TIMP1 expression, and TIMP1 activity was demonstrated in reverse zymography test.

MMP1a and MMP1b (interstitial collagenase) secreted by mice and rats represent orthologues of the human interstitial collagenase MMP1. MMP1a is able to degrade type I, II and III fibrillar collagen $(99,100)$. It is produced by fibroblasts as procollagenase (101) and is activated by MMP3 (stromelysin) (102). Its expression in human synovial fibroblasts has been shown to be stimulated by TNF (103). It is also produced by LPS-stimulated macrophages $(83,104)$ and by endothelial cells particularly after stimulation by TNF (105). Both MMP1 and MMP3 are also expressed in adipocytes stimulated by TNF (96). In our study, LPS and TNF moderately stimulated both MMP1a and MMP1b mRNA expression (Fig. 4a and b). TGF-ß1 decreased the mRNA levels of MMP1a and MMP1b, similarly to that in the study of Bujor et al (106) in human dermal fibroblasts, but IL-4 had no effect (Fig. 4c and d). The activity of MMP1a and MMP1b in supernatants was not detected by casein zymography.

The expression of the remaining three MMPs studied, that is MMP3 (stromelysin 1), MMP13 (collagenase 3) and MMP14 (MT1-MMP; membrane metalloproteinase), in the synovial membranes, was only weakly stimulated by LPS (Fig. 4a). Increased production of MMP3 has been observed in fibroblast-like synoviocytes after their stimulation with LPS (52). It has also been reported to be produced by LPS stimulated alveolar macrophages, but in considerably lower amount than by fibroblasts (83). TNF has been shown to stimulate the expression of both MMP3 and MMP13 and surprisingly to decrease the expression of MMP14 (Fig. 4b), an effect opposite to that observed in cardiac fibroblasts (107). MMP3 expression has also been observed in endothelial cells and adipocytes and was shown to be augmented after TNF stimulation $(96,105)$. MMP13 expression has been reported to be stimulated in fibroblasts by LPS (108) and TNF (109).

TIMPs. TIMPs are produced by a variety of cells and are present in most tissues, but their expression is individually regulated by cytokines and depends on the cell type. TIMPs 1,2 and 4 are secreted into the medium, while TIMP 3 is predominantly matrix-associated $(98,110)$. LPS has been reported to stimulate TIMP1 expression and production by alveolar macrophages $(91,104)$ or by human monocytes $(93)$. TIMP1 mRNA expression was observed to be markedly increased in dermal fibroblasts after TNF treatment (111). In endothelial cells, TNF had no effect on TIMP1 and TIMP2 mRNA levels and did not induce TIMP3 or TIMP4 expression (105). IL-4 decreased TIMP1 production in monocytes (93). Production of TIMP2 in dermal fibroblasts at the mRNA and protein levels was shown to be stimulated 
by IL-4, but not by TGF-ß1 (112). TGF- 31 has been shown to induce expression of both TIMP1 and TIMP3 in human synovial lining cells (113). Moreover, increased expression of TIMP3, under influence of TGF- $\beta 1$, has been observed in fibroblasts (114).

In our work LPS increased the mRNA expression of TIMP1 and TIMP3 in the synovial membrane, while the expression of TIMP2 and TIMP4 decreased (Fig. 4a). Stimulation by TNF was much weaker but qualitatively similar to that produced by LPS, with the exception of the TIMP3 mRNA expression which decreased (Fig. 4b). TGF- 31 considerably raised the expression of TIMP3 and decreased the expression of TIMP1, TIMP2 and TIMP4 (Fig. 4d). IL-4 slightly, but significantly, decreased the expression of all TIMPs (Fig. 4c). TIMP1, TIMP2 and TIMP4 were detected by Western blot analysis in similar amounts in supernatants from all control and experimental groups (Fig. 7). Only TIMP1 was detected by reversed zymography and no difference was observed between control and stimulated membranes.

In this study we attempted to accomplish the general characterization of the synovial membrane response to a few biologically active factors known to influence various cell types at least nominally analogous to those present in the synovial membrane. A precise comparison of cytokine expression at the mRNA and protein level in the rat synovial membrane with data for particular cell types presented by other authors is difficult, due to the difference in the origin of the cells (human vs. murine), their various modifications in culture, the differences in the period of observation and the dosage of the stimulating agents. Nevertheless, even with these limitations, is seems that the responses of the synovial membrane to LPS, TNF, TGF- $\beta 1$ and IL-4 are essentially similar to those reported in the papers mentioned above and can be explained by the activity of all of the particular cell types present in the membrane, although their individual contribution is difficult to estimate. The expression, secretion and activity of MMPs and TIMPs in the synovial membrane represents a summary of the activities of its various cell populations but cannot be predicted on the basis of analysis of particular cell types forming the tissue. This is particularly evident in the case of MMP2, whose expression and activity according to data obtained by others working with pure cell populations should have been increased after LPS stimulation, but resulted in a decrease in our system of the whole synovial membrane.

\section{Acknowledgements}

This study was supported by a grant from the Ministry of Sciences and Higher Education (N N401 0490 33).

\section{References}

1. Gardner E, Gray DJ and O'Rahilly R: Joints. In: Anatomy. WB Saunders Company (ed), Philadelphia, London, p25, 1960.

2. Levick JR, Price FM and Mason RM: Synovial matrixsynovial fluid system of joints. In: Extracellular Matrix. Vol 1. Comper WD (ed). Harwood Academic Publishers, Amsterdam, pp328-376, 1996.

3. Wilkinson LS, Pitsillides AA, Worrall JG and Edwards JCW: Light microscopic characterization of the fibroblast-like synovial intimal cell (synoviocyte). Arthritis Rheum 35: 1179-1184, 1992.
4. Barland P, Novikoff AB and Hamerman D: Electron microscopy of the human synovial membrane. J Cell Biol 14: 207-215, 1962.

5. Henderson B: The synovial lining cell and synovitis. Scand J Rheumatol 17 (Suppl. 76): S33-S38, 1988.

6. Revell PA, al-Saffar N, Fish S and Osei D: Extracellular matrix of the synovial intimal cell layer. Ann Rheum Dis 54: 404-407, 1995.

7. Moghaddami M, Celland LG and Mayrhofer G: MHC II+ CD45+ cells from synovium-rich tissues of normal rats: phenotype, comparison with macrophage and dendritic cell lineages and differentiation into mature dendritic cells in vitro. Int Immunol 17: 1103-1115, 2005.

8. Moghaddami M, Mayrhofer G and Celland LG: MHC class II compartment, endocytosis and phagocytic activity of macrophages and putative dendritic cells isolated from normal tissues rich in synovium. Int Immunol 17: 1117-1130, 2005.

9. Nozawa-Inoue K, Amizuka N, Ikeda N, Suzuki A, Kawano Y and Maeda T: Synovial membrane in the temporomandibular joint - its morphology, function and development. Arch Histol Cytol 66: 289-306, 2003

10. Klareskog L, Forsum U, Kabelitz D, Plöen L, Sundström C, Nillson K, Wigren $\mathrm{A}$ and Wigzell $\mathrm{H}$ : Immune functions of synovial cells: phenotyppic and $\mathrm{T}$ cell regulatory properties of macrophage-like cells that express HLA-DR. Arthritis Rheum 25: 488-501, 1982 .

11. Dijkstra CD, Dopp EA, Vogels IM and Van Noorden CJF: Macrophages and dendritic cells in antigen-induced arthritis. Scand J Immunol 26: 513-523, 1987.

12. Kakudo K, Takasu J and Yamamoto Y: Ultrastructural observations of horseradish peroxidase in synovial lining cells of the rats' temporomandibular joint. J Dent Res 56: 1376, 1977.

13. Senda H, Sakuma E, Wada I, Wang HJ, Maruyama H and Matsui N: Ultrastructural study of cells at the synoviumcartilage junction: response of synovial cells of the rat knee to intra-articularly injected latex particles. Kaibogaku Zasshi 74: 525-535, 1999.

14. Linck $G$ and Porte A: Cytophysiology of the synovial membrane: distinction of two types of cells of the intima revealed by their reaction with horseradish peroxidase and iron saccharate in the mouse. Biol Cell 42: 147-152, 1981.

15. Okada Y, Nakanishi I and Kajikawa K: Ultrastructure of the mouse synovial membrane. Development and organization of the extracellular matrix. Arthitis Rheum 24: 835-843, 1981.

16. Graabæk PM: Absorption of intraarticularly injected horseradish peroxidase in synoviocytes of rat synovial membrane: an ultrastructural-cytochemical study. J Ultrastruct Res 92: 86-100, 1985.

17. Stuhlmeier KM and Pollaschek CP: Differential effect of transforming growth factor $B$ (TGF- 31 ) on the genes encoding hyaluronan synthases and utilization of the p38 MAPK pathway in TGF-ß31-induced hyaluronan synthase 1 activation. J Biol Chem 279: 8753-8760, 2004.

18. Stuhlmeier KM and Pollaschek CP: Adenovirus-mediated gene transfer of mutated $\mathrm{I} \kappa \mathrm{B}$ kinase and $\mathrm{I} \kappa \mathrm{B}$ a reveal $\mathrm{NF}-\kappa \mathrm{B}$ dependent as well as $\mathrm{NF}-\kappa \mathrm{B}$-independent pathways of HAS1 activation. J Biol Chem 280: 42766-42773, 2005.

19. Worrall JG, Bayliss MT and Edwards JCW: Morphological localization of hyaluronan in normal and diseased synovium. J Rheumatol 18: 1466-1472, 1991.

20. Anggiansah CL, Scott D, Poli A, Coleman PJ, Badrick E, Mason RM and Levick JR: Regulation of hyaluronan secretion into rabbit synovial joints in vitro by protein kinase C. J Physiol 550: 631-640, 2003.

21. Swann DA: Structure and function of lubricin, the glycoprotein responsible for the boundary lubrication of articular cartilage. In: Articular Synovium. Franchimont $\mathrm{P}$ and Karger S (eds). Basel, pp45-58, 1982.

22. Edwards JCW: Fibroblast biology: Development and differentiation of synovial fibroblasts in arthritis. Arthritis Res 2: 344-347, 2000.

23. Mapp PI and Revel PA: Fibronectin production by synovial intimal cells. Rheumatol Int 5: 229-237, 1985.

24. Nozawa-Inoue K, Ajima H, Takagi R and Maeda T: Immunocytochemical demonstration of laminin in the synovial lining layer of the rat temporomandibular joint. Arch Histol Cytol 44: 531-534, 1999.

25. Wilkinson LS, Edwards JCW, Poston RN and Haskard DO: Expression of vascular cell adhesion molecule-1 in normal and inflamed synovium. Lab Invest 68: 82-88, 1993. 
26. Valentia X, Higgins JM, Kiener HP, Lee DM, Podrebarac TA, Dascher CC, Watts GF, Mizoguchi E, Simmons B, Patel DD, Bhan AK and Brenner MB: Cadherin-11 provides specific cellular adhesion between fibroblast-like synoviocytes. J Exp Med 200: 1673-1679, 2004.

27. Andoh E, Kawano Y, Ajima H, Nozawa-Inoue K, Kohno S and Maeda T: Expression of $25 \mathrm{kDa}$ heat shock protein by synovial type B cells of the mouse temporomandibulat joint. Arch Oral Biol 46: 947-954, 2001

28. Nozawa-Inoue K, Oshima H, Kawano Y, Yamamoto H, Takagi R and Maeda T: Immunocytochemical demonstration of heat shock protein 25 in the rat temporomandibular joint. Arch Histol Cytol 62: 483-491, 1999.

29. Shikichi M, Kitamura HP, Yanase H, Konno A, TakahashiIwanaga $\mathrm{H}$ and Iwanaga $\mathrm{T}$ : Three-dimentional ultrastructure of synoviocytes in the horse joint as revealed by the scanning electron microscope. Arch Histol Cytol 62: 219-229, 1999.

30. Iwanaga T, Shikichi M, Kitamura H, Yanase H and NozawaInoue K: Morphology and functional roles of synoviocytes in the joint. Arch Histol Cytol 63: 17-31, 2000.

31. Huber LC, Distler O, Tarner I, Gay RE, Gay S and Pap T: Synovial fibroblasts: key players in rheumatoid arthritis. Rheumatology 45: 669-675, 2006.

32. Kinne RW, Stuhlmüller B and Burmester GR: Cells of the synovium in rheumatoid arthritis. Macrophages. Arthritis Res Ther 9: 224, 2007

33. Bondeson J, Wainwright SD, Lauder S, Amos N and Hughes CE: The role of synovial macrophages and macrophage-produced cytokines in driving aggrecanases, matrix metalloproteinases, and other destructive and inflammatory responses in osteoarthritis. Arthritis Res Ther 8: R187, 2006.

34. Schwachula A, Riemann D, Kehlen A and Langner J: Characterization of the immunophenotype and functional properties of fibroblast-like synoviocytes in comparison to skin fibroblasts and umbilical vein endothelial cells. Immunobiology 190: 67-92, 1994.

35. Sweet MJ and Hume DA: CSF-1 as a regulator of macrophage activation and immune responses. Arch Immunol Ther Exp 51: 169-177, 2003

36. Galley HF and Webster NR: Physiology of the endothelium. $\mathrm{Br}$ J Anaesth 93: 105-113, 2004.

37. Kern PA, Saghizadeh M, Ong JM, Bosch RJ, Deem R and Sinsolo RB: The expression of tumor necrosis factor in human adipose tissue. J Clin Invest 95: 2111-2119, 1995.

38. Dumond H, Presle N, Terlain B, Mainard D, Loeuille D, Netter P and Pottie P: Evidence for a key role of leptin in osteoarthritis. Arthritis Rheum 48: 3118-3129, 2003.

39. Ehling A, Schäffler A, Herfarth H, Tarner IH, Anders S, Distler O, Paul G, Distler J, Gay S, Schölmerich J, Neumann E and MüllerLadner U: The potential of adiponectin in driving arthritis. J Immunol 176: 4468-4478, 2006.

40. Mohamed-Ali V, Goodrick S, Ravesh A, Katz DR, Miles JM, Yudkin JS, Klein S and Coppack SW: Subcutaneous adipose tissue releases interleukin-6, but not tumor necrosis factor - in vivo. J Clin Endocrinol Metab 82: 4196-4200, 1997.

41. Hyc A, Osiecka-Iwan A, Niderla-Bielinska J, Jankowska-Steifer E and Moskalewski S: Pro- and anti-inflammatory cytokines increase hyaluronan production by rat synovial membrane in vitro. Int J Mol Med 24: 579-585, 2009.

42. Hyc A, Osiecka-Iwan A and Moskalewski S: Preparation of rat synovial membrane for studies of cytokine secretion. Folia Histochem Cytobiol 45: 57-60, 2007

43. Scotté M, Hiron M, Masson S, Lyoumi S, Banine F, Téniére P, Lebreton JP and Daveau M: Differential expression of cytokine genes in monocytes, peritoneal macrophages and liver following endotoxin- or turpentine-induced inflammation in rat. Cytokine 8: $115-120,1996$.

44. Fiorentino DF, Zlotnik A, Mosmann TR, Howard M and O'Garra A: IL-10 inhibits cytokine production by activated macrophages. J Immunol 147: 3815-3822, 1991

45. Mukherjee S, Chen L-Y, Papadimos TJ, Huang S, Zuraw BL and Pan ZK: Lipopolisaccharide driven Th2 cytokine production in macrophages is regulated by both MyD88 and TRAM. J Biol Chem 284: 29391-29398, 2009.

46. Hofman C, Lorenz K, Braithwaite SS, Colca JR, Palazuk BJ, Hotamisligil GS and Spiegelman BM: Altered gene expression for tumor necrosis factor-alpha and its receptors during drug and dietary modulation of insulin resistance. Endocrinology 134: 264-270, 1994
47. Distel E, Cadoudal T, Durant S, Poignard A, Chevalier X and Benelli C: The intrapatellar fat pad in knee osteoarthritis. An important source of interleukin-6 and its soluble receptor. Arthritis Rheum 60: 3374-3377, 2009.

48. Hoch M, Eberle AN, Peterli R, Peters T, Seboek D, Keller U, Muller B and Linscheid P: LPS induces interleukin-6 and interleukin- 8 but not tumor necrosis factor- $\alpha$ in human adipocytes. Cytokine 41: 29-37, 2008.

49. Moskalewski S, Osiecka-Iwan A, Hyc A and Niderla J: Cartilage formed by syngeneic rat chondrocytes in joint surface defects is rejected in animals sensitized with allogeneic chondrocytes: involvement of the synovial lining. Arch Immunol Ther Exp 53: $159-168,2005$.

50. Xing Z, Jordana M, Kirpalani H, Driscoll KE, Schall TJ and Gauldie J: Cytokine expression by neutrophils and macrophages in vivo: endotoxin induces tumor necrosis factor-alpha, macrophage inflammatory protein-2, interleukin-1 beta, and interleukin-6 but not RANTES or transforming growth factorbeta 1 mRNA expression in acute lung inflammation. Am J Respir Cell Mol Biol 10: 148-153, 1994.

51. Jirik FR, Podor TJ, Hirano T, Kishimoto T, Loskutoff DJ, Carson DA and Lotz M: Bacterial lipopolysaccharides and inflammatoty mediators augment IL-6 secretion by human endothelial cells. J Immunol 142: 144-147, 1989.

52. Santangelo KS, Johnson AL, Ruppert AS and Bertone AL: Effects of hyaluronan treatment on lipopolysaccharide-challenged fibroblast-like synovial cells. Arthtitis Res Ther 9: R1, 2007.

53. Batista ML Jr, Santos RV, Cunha LM, Mattos K, Oliveira EM, Seelaender MC and Costa Rosa LF: Changes in the proinflammatory cytokine production and peritoneal macrophage function in rats with chronic heart failure. Cytokine 34: 284-290, 2006.

54. Suttles J, Giri JG and Mizel SB: IL-1 secretion by macrophages. Enhancement of IL-1 secretion and processing by calcium jonofores. J Immunol 144: 175-182, 1990.

55. Dayer JM: The process of identifying and understanding cytokines: from basic studies to treating rheumatic diseases. Best Pract Res Clin Rheumatol 18: 31-45, 2004.

56. Pober JS and Cotran RS: Cytokines and endothelial cell biology. Physiol Rev 70: 427-451, 1990.

57. Fain JN: Release of interleukins and other inflammatory cytokines by human adipose tissue is enhanced in obesity and primarily due to the nonfat cells. Vitam Horm 74: 443-447, 2006.

58. Kuruvilla L and Kartha CC: Treatment with TNF- $\alpha$ or bacterial lipopolisaccharide attenuates endocardial endothelial cellmediated stimulation of cardiac fibroblasts. J Biomed Sci 16: 21: 16-21, 2009

59. Lee HC, Vinodhumar R, Yoon JW, Park SK, Lee CW and Kim HY: Enhanced inhibitory effect of ultra-fine granules of red ginseng on LPS-induced cytokine expression in the monocyte-derived macrophage THP-1 cells. Int J Mol Sci 9: $1379-1392,2008$

60. Bauer J, Ganter U, Geiger T, Jacobshagen U, Hirano T, Matsuda T, Kishimoto T, Andus T, Acs G, Gerok W and Ciliberto G: Regulation of interleukin-6 expression in cultured human blood monocytes and monocyte-derived macrophages. Blood 72: $1134-1140,1988$

61. Elias JA and Lentz V: IL-1 and tumor necrosis factor synergistically stimulate fibroblast IL-16 production and stabilize IL-6 messenger RNA. J Immunol 145: 161-166, 1990.

62. Eickelberg O, Pansky A, Mussmann R, Bihl M, Tamm M, Hikdebrand P, Perruchoud AP and Roth M: Transforming growth factor- $\beta 1$ induces interleukin- 6 expression via activating protein-1 consisting of Jun D homodimers in primary human lung fibroblasts J Biol Chem 274: 12933-12938, 1999.

63. Seong GJ, Hong S, Jung S-A, Lee J-J, Lim E, Kim S-J and Lee JH: TGF-beta-induced interleukin-6 participates in transdifferentiation of human Tenon's fibroblasts to myofibroblasts. Mol Vis 15: 2123-2128, 2009

64. Turner M, Chantry D and Feldmann M: Transforming growth factor $\beta$ induces the production of interleukin 6 by human peripheral blood mononuclear cells. Cytokine 2: 211-216, 1990.

65. Musso T, Espinoza-Delgado I, Pulkki K, Gusella GL, Longo DL and Varesio L: IL-2 induces IL-6 production in human monocytes. J Immunol 148: 795-800, 1992.

66. Espevik T, Figari IS, Shalaby MR, Lackides GA, Lewis GD, Shepard HM and Palladino MA Jr: Inhibition of cytokine production by cyclosporin A and transforming growth factor $B$. J Exp Med 166: 571-576, 1987. 
67. Bogdan $\mathrm{C}$ and Nathan $\mathrm{C}$ : Modulation of macrophage function by transforming growth factor $B$, interleukin-4, and interleukin 10. Ann NY Acad Sci 23: 713-739, 1993.

68. Bogdan C, Paik J, Vodovots Y and Nathan C: Contrasting mechanisms for suppression of macrophage cytokine release by transforming growth factor- $\beta$ and interleukin-10. J Biol Chem 267: 23301-23308, 1992

69. Turner M, Chantry D, Katsikis P, Berge A, Brenna FM and Feldmann $\mathrm{M}$ : Induction of interleukin 1 receptor antagonis protein by transforming growth factor-ß. Eur J Immunol 21: $1635-1639,1991$

70. Chantry D, Turner M, Abney E and Feldmann M: Modulation of cytokine production by transforming growth factor- $\beta$. J Immunol 142: 4295-4300, 1989

71. Piek E, Ju WJ, Heyer J, Escalante-Alcadle D, Steward CL, Weinstein M, Deng C, Kucherlapati R, Böttinger EP and Roberts A: Functional characterization of transforming growth factor b signaling in Smad2- and Smad3- deficient fibroblasts. J Biol Chem 276: 19945-19953, 2001

72. Kim S-J, Angel P, Lafyatis R, Hattori K, Kim KY, Sporn MB, Karin $\mathrm{M}$ and Roberts AB: Autoinduction of transforming growth factor $\beta 1$ is mediated by the AP- 1 complex. Mol Cell Biol 10: 1492-1497, 1990.

73. Van Obberghen-Schilling E, Roche NS, Flanders KC, Sporn MB and Roberts $\mathrm{AB}$ : Transforming growth factor $B 1$ positively regulates its own expression in normal and transformed cells. J Biol Chem 263: 7741-7746, 1988.

74. Donnelly RP, Crofford LJ, Freeman SL, Buras J, Remmers E, Wilder RL and Fenton MJ: Tissue specific regulation of IL-6 production by IL-4. Differential effects of IL-4 on nuclear factor- $\kappa \mathrm{B}$ activity in monocytes and fibroblasts. J Immunol 151: 5603-5612, 1993.

75. Lacraz S, Nicod L, Galve-de Rochemonteix B, Baumberger C, Dayer J-M and Welgus HG: Suppression of metalloproteinase biosynthesis in human alveolar macrophages by interleukin-4. J Clin Invest 90: 382-388, 1992

76. Colotta F, Sironi M, Borrè A, Luini W, Maddalena F and Mantovani A: Interleukin 4 amplifies monocyte chemotactic protein and interleukin 6 production by endothelial cells. Cytokine 4: 24-28, 1992

77. Howell G, Pham P, Taylor D, Foxwell B and Feldman M: Interleukin 4 induces interleukin 6 production by endothelial cells; synergy with interferon- $\gamma$. Eur J Immunol 21: 97-101, 1991.

78. Te Velde AA, Huijbens RJ, Heije K, de Vries JE and Figdor CG Interleukin-4 (IL-4) inhibits secretion of IL-1 beta, tumor necrosis factor alpha, and IL-6 by human monocytes. Blood 76: 1392-1397, 1990

79. Okada Y, Morodomi T, Enghild JJ, Suzuki K, Yasui A, Nakanishi I, Salvesen G and Nagase H: Matrix metalloproteinase 2 from human rheumatoid synovial fibroblasts. Purification and activation of the precursor and enzymic properties. Eur J Biochem 194: 721-730, 1990.

80. Ohuchi E, Imai K, Fujii Y, Sato H, Seiki M and Okada Y: Membrane type 1 matrix metalloproteinase digests interstitial collagens and other extracellular matrix macromolecules. J Bio Chem 272: 2446-2451, 1997.

81. Chang Y-C, Yang S-F, Lai C-C, Liu J-Y and Hsieh Y-S: Regulation of matrix metalloproteinase production by cytokines, pharmacological agents and periodontal pathogens in human periodontal ligament fibroblast cultures. J Periodontal Res 37: 196-203, 2002.

82. Clegg PD and Carter SD: Matrix metalloproteinase-2 and -9 are activated in joint disease. Equine Vet J 31: 324-330, 1999.

83. Welgus HG, Campbell EJ, Cury JD, Eisen AZ, Senior RM Wilhelm SM and Goldberg GI: Neutral metalloproteinases produced by human mononuclear phagocytes. J Clin Invest 86 : 1494-1502, 1990

84. Lamoreaux WJ, Fitzgerald MEC, Reiner A, Hasty KA and Charles ST: Vascular endothelial growth factor increases release of gelatinase $\mathrm{A}$ and decreases release of tissue inhibitor of metalloproteinases by microvascular endothelial cell in vitro. Microvasc Res 55: 29-42, 1998.

85. Taraboletti G, D'Ascenzo S, Borsotti P, Giavazzi R, Pavan A and Dolo V: Shedding of matrix metalloproteinases MMP2, MMP9, and MT1/MMP as membrane vesicle-associated components by endothelial cells. Am J Pathol 160: 673-680, 2002.

86. Puyraimond A, Weitzman JB, Babiole E and Menashi S Examining the relationship between the gelatinolytic balance and the invasive capacity of endothelial cells. J Cell Sci 112: $1283-1290,1999$.
87. Kim HG and Koh GY: Lipopolysaccharide activates matrix metalloproteinase-2 in endothelial cells through an NF- $\mathrm{B}$ dependent pathway. Biochem Biophys Res Comm 269: 401-405, 2000.

88. Moon H-S, Lee H-G, Seo J-H, Chung C-S, Guo D-D, Kim T-G, Choi Y-J and Cho C-S: Leptin induced matrix metalloproteinase-2 secretion is suppressed by trans-1-,cis-12 conjugated linoleic acid. Biochem Biophys Res Comm 356: 955-960, 2007.

89. Atkinson JJ and Senior RM: Matrix metalloproteinase-9 in lung remodelling. Am J Respir Cell Mol Biol 28: 12-24, 2003.

90. Goldberg GI, Strongin A, Collier IE, Genrich LT and Marmer BL: Interaction of 92-kDa type IV collagenase with the tissue inhibitor of metalloproteinases prevents dimerization, complex formation with interstitoal collagenase, and activation of the proenzyme with stromelysin. J Biol Chem 267: 4583-4591, 1992.

91. Shapiro SD, Fliszar CJ, Broekelmann TJ, Mecham RP, Senior RM and Welgus HG: Activation of the 92-kDa gelatinase by stromelysin and 4-aminophenylmercuric acetate. J Biol Chem 270: 6351-6356, 1995

92. Sarén P, Welgus HG and Kovanen PT: TNF- $\alpha$ and IL-1B selectively induce expression of $92-\mathrm{kDa}$ gelatinase by human macrophages. J Immunol 157: 4159-4165, 1996.

93. Zhang Y, McCluskey K, Fujii K and Wahl LM: Differential regulation of monocyte matrix metalloprotease and TIMP1 production by $\mathrm{TNF}-\alpha$, granulocyte-macrophage CSF, and IL-1ß through prostaglandin-dependent mechanism. J Immunol 61: 3071-3076, 1998.

94. Lepidi S, Kenagy RD, Raines EW, Chiu ES, Chair A, Ross R and Clowes A: MMP9 production by human monocyte-derived macrophages is decreased on polymerized type I collagen. J Vasc Surg 34: 1111-1118, 2001.

95. Partridge CA, Jeffrey JJ and Malik AB: A 96-kDa gelatinase induced by TNF-alpha contributes to increased microvascular endothelial permeability. Am J Physiol 265: L438-L447, 1993.

96. O'Hara A, Lim F-L, Mazzatti DJ and Trayhurn P: Microarray analysis identifies matrix metalloproteinases (MMPs) as the genes whose expression is up-regulated in human adipocytes by macrophage-conditioned medium. Pflugers Arch 458: 1103-1114, 2009

97. Cawston TE: Proteinases and inhibitors. Br Med Bull 51: 385-401, 1995.

98. Baker AH, Edwarda DR and Murphy G: Metalloproteinase inhibitors: biological action and therapeutic opportunities. J Cell Sci 115: 3719-3727, 2002

99. Balbin M, Fueyo A, Knäuper V, López JM, Álvarez J, Sánchez LM, Quesada V, Bordallo J, Murphy M and LópezOtín C: Identification and enzymatic characterization of two diverging murine counterparts of human interstitial collagenase (MMP-1) expressed at sites of embryo implantation. J Biol Chem 276: 10253-10262, 2001.

100.Pearse E, Tregouet D-A, Samnegård A, Morgan AR, Cox C, Hamsten A, Eriksson P and Ye S: Haplotype effect of the matrix metalloproteinase-1 gene on risk of myocardial infarction. Circ Res 97: 1070-1076, 2005.

101. Stricklin GP, Bauer EA, Jeffrey JJ and Eisen AZ: Human skin collagenase: isolation of precursor and active forms from both fibroblasts and organ cultures. Biochemistry 16: 1607-1615, 1977.

102. Suzuki K, Enghild JJ, Morodomi T, Salvesen G and Nagase H: Mechanisms of activation of tissue procollagenase by matrix metalloproteinase 3 (stromelysin). Biochemistry 29: 1026110270,1990

103. Dayer J-M, Beutler B and Cerami A: Cachectin/tumor necrosis factor stimulates collagenase and prostaglandin E2 production by human synovial cells and dermal fibroblasts. J Exp Med 162: 2163-2168, 1985 .

104. Cury JD, Campbell EJ, Lazarus CJ, Albin RJ and Welgus HG: Selective up-regulation of human alveolar macrophage collagenase production by liposaccharide and comparison to collagenase production by fibroblasts. J Immunol 141: 4306-4312, 1988 .

105. Nelimarkka LO, Nikkari ST, Ravanti LS, Kähäri VM and Järveläinen HT: Collagenase-1, stromelysin-1 and 92 kDa gelatinase are associated with tumor necrosis factor-alpha induced morphological change of human endothelial cells in vitro. Matrix Biol 17: 293-304, 1998

106. Bujor AM, Pannu J, Bu S, Smith EA, Muise-Helmericks RC and Trojanowska M: Akt blockade downregulates collagen and upregulates MMP1 in human dermal fibroblasts. J Invest Dermatol 128: 1906-1914, 2008. 
107. Awad AE, Kandalan V, Chakrabarti S, Wang X, Penninger JM, Davidge ST, Oudit GY and Kassiri Z: Tumor necrosis factor induces matrix metalloproteinases in cardiomyocytes and cardiofibroblasts differentially via superoxide production in a P13K \{gamma\}-dependent manner. Am J Physiol Cell Physiol 298: 679-692, 2010.

108. Rossa C Jr, Min L, Bronson P and Kirkwood KL: Transcriptional activation of MMP13 by periodontal pathogenic LPS requires p38 MAP kinase. J Endotoxin Res 13: 85-93, 2007.

109. Rossa C Jr, Liu M, Patil C and Kirkwood KL: MKK3/6-p38 MAKP negatively regulates murine MMP13 gene expression induced by IL-1 beta and TNF-alpha in immortalized periodontal ligament fibroblasts. Matrix Biol 7: 478-488, 2005.

110. Gomez DE, Alonso DF, Yoshiji H and Thorgeirsson UP: Tissue inhibitors of metalloproteinases: structure, regulation and biological functions. Eur J Cell Biol 74: 111-112, 1997.
111.Dasu MR, Barrow RE, Spies M and Herndon DN: Matrix metalloproteinase expression in cytokine stimulated dermal fibroblasts. Burns 29: 527-531, 2003.

112. Ihn H, Yamane K, Asano Y, Kubo M and Tamaki K: IL-4 upregulates the expression of tissue inhibitor of metalloproteinase-2 in dermal fibroblasts via the p38 mitogenactivated protein kinase-dependent pathway. J Immunol 168: 1895-1902, 2002.

113. Gatsios P, Haubeck HD, Van de Leur E, Frisch W, Apte SS, Greiling H, Heinrich OC and Graeve L: Oncostatin M differentially regulates tissue inhibitors of metalloproteinases TIMP1 and TIMP3 gene expression in human synovial lining cells. Eur J Biochem 24: 56-63, 1996.

114.Leco KJ, Khokha R, Pavloff N, Hawkes SP and Edwards DR: Tissue inhibitor of metalloproteinases 3 (TIMP3) is an extracellular matrix-associated protein with a distinctive pattern of expression in mouse cells and tissues. J Biol Chem 269: 9352-9360, 1994. 